\title{
EMERGING CONTEMPORARY ARTISTS: A COMPARATIVE STUDY OF ERTIBIL BIZKAIA AND ARTESHOP BILBAO*
}

\section{Arturo Cancio Ferruz}

Universidad del País Vasco / Euskal Herriko Unibertsitatea. Dpto. Arte y Tecnología. Doctorando

\author{
Jabier Martínez López \\ Universidad de Deusto
}

\begin{abstract}
Ertibil Bizkaia and Arteshop Bilbao are two publicly financed institutional calls for the promotion of emerging artists in the context of the Basque Country, with both distinct and similar characteristics. In this paper, we examine the regulations that base the functioning of these calls to analyse the distribution of the budgets both programmes allocate to compensate for the work of the participant artists, during the period from 2012 and 2016. We also pay attention to the results of the competitive tenders of the artists in terms of concurrence and participation. The results confirm the main features of Thorsby's theory of artists' work preference (1994) and Frank and Cook's (1995) theory of winner-take-all markets.
\end{abstract}

Keywords: ARTISTIC INSTITUTIONAL CALLS; ERTIBIL (PROVINCIAL COUNCIL OF BIZKAIA CALL); ARTESHOP (BILBAO SHOPS' CALL); ECONOMICS; PUBLIC FINANCE

\section{ARTISTAS CONTEMPORÁNEOS EN EMERGENCIA: ESTUDIO COMPARATIVO DE ERTIBIL BIZKAIA Y ARTESHOP BILBAO}

\section{Resumen}

Ertibil Bizkaia y Arteshop Bilbao son dos convocatorias institucionales financiadas con fondos públicos, para la promoción de artistas emergentes en el contexto del País Vasco, con características tanto distintivas como similares. En este trabajo, examinamos las regulaciones en las que se basan el funcionamiento de estas convocatorias, para analizar la distribución de los presupuestos que ambos programas asignan ala compensación del trabajo de los artistas participantes, durante el período comprendido entre 2012 y 2016. También prestamos atención a los resultados de las licitaciones competitivas de los artistas en términos de concurrencia y participación. Los resultados confirman las principales características de la teoría de Thorsby sobre la preferencia de trabajo de los artistas (1994) y la teoría de Frank y Cook (1995) sobre los mercados donde el ganador se lleva todo.

Palabras clave: CONVOCATORIAS ARTÍSTICAS INSTITUCIONALES; ERTIBIL (CONVOCATORIA DIPUTACIÓN FORAL DE BIZKAIA); ARTESHOP (CONVOCATORIA COMERCIOS BILBAO); ECONOMÍA; FINANZAS PÚBLICAS

\footnotetext{
Cancio Ferruz, Arturo \& Jabier Martínez López. "Emerging contemporary artists: A comparative study of ErtibilBizkaia and Arteshop Bilbao“. AusArt 5(2): 9-26. DOI: 10.1387/ausart.18771
} 


\section{INTRODUCTION}

Ertibil Bizkaia and Arteshop Bilbao are two institutional calls financed with public funds to support new artists. Their programs aim to bring the work of little-known artists to broad sectors of society, promote them in the initial stages of their careers and promote their professionalization.

The Provincial Council of Bizkaia (DFB-BFA), executive and governing body of this Historical Territory, finances and organises Ertibil in its entirety, since its start-up in 1984. Seven years later, according to Romo (Romo 1999, 218), several representatives of the Basque Administrations and the Solomon R. Guggenheim Foundation begin the talks that make possible the inauguration of the Guggenheim Museum Bilbao in 1997.

In his article, Romo also affirms that the main political reasons that motivate this agreement lie in the necessary regeneration of the city of Bilbao, through the construction of a series of cultural facilities. This operation intends to overcome the crisis of the traditional heavy industry which mainly bases the economy of the province of Bizkaia at that time (219).

It is precisely at the end of the eighties when the concept of the creative city emerges (Landry 2005, 2) and its unstoppable diffusion begins. There is, therefore, a political will to make the city of Bilbao an international referent as a creative city, "... an emotionally satisfying city that stimulates creativity among its citizens" (Yencken 1988, 597), through the promotion of art.

In turn, Arteshop is a contest organized by the Bilbao City Council, through the public entity Bilbao Ekintza, E.P.E.L., the University of the Basque Country -and fundamentally the Faculty of Fine Arts at this University-, and Bilbao Art Foundation collaborate in its organization.

It emerged in 2011, when Guggenheim museum is already a successfully consolidated reality. The so-called 'Guggenheim effect', internationally recognized, emerges as the symbol of the long sought industrial regeneration of Bilbao and the economy of the Basque Country as a whole (Plaza 1999; Plaza, Tironi \& Haarich 2009).

In this sense, although long before Adorno and Horkheimer already present the term cultural industry (1944), it is basically from the publication of the work 
of Landry and Bianchini (1995) and Florida (2002) when the new phenomenon of the creative industries becomes the object of a profound academic debate.

In fact, it is Landry who, together with Hyams, get credit for the creation of an index of creative cities ${ }^{1}$, conceived and developed in collaboration with the association Bilbao Metrópoli 30 and Bizkaia Xede, between 2008 and 2009. The data these authors take into account for the assessment of creative cities derive from very different sectors, including education and instruction at all levels, as well as the fields of art and culture.

Consequently, the timeframe in which we set out the events above, between the end of the eighties and the present, take us to consider that the analysis of these two calls, Ertibil and Arteshop, can offer a vision of a particular evolution. One of these calls for the promotion of emerging artists examined appears before the emergence of the notion of creative city, while the other does it after this notion experiments a notorious and critical development, both local and internationally.

Besides, we assume it is possible to observe some changes already occurring in the formative stages of the artists, through the detailed examination of these contests. We expect to find some parallelisms or pattern of reproduction that replicate in the art system as a whole. In fact, Arteshop and Ertibil present a series of characteristics that define both contests and that are studied in this section.

Also, among the defining features of these two calls, it is possible to find both differences and similarities. Among them, we firstly point out that Ertibil operates as an itinerant exhibition, touring several municipal exhibition halls in the province of Bizkaia. In its turn, Arteshop makes it possible the presence of artworks in a large number of private commercial establishments, not included in the category of specific spaces for the presentation of works of art.

Secondly, both programs propose similar competitive systems for the selection of the artists who request to participate and incorporate a contest that includes monetary prizes for some of the artists finally selected. However, while Arteshop destines some funds to pay the artists for their work and the materials needed to produce them, the artists who aspire to participate in Ertibil must either self-finance or request external aid and/or scholarships for this same purpose. 
Thirdly, Ertibil selects a lower number of artists than Arteshop. Finally, Arteshop introduces the figure of artist-tutor. Thus, a selection of artists from Bilbao Arte Foundation supervise the works of the participants in the contest and, besides, they realize their own artistic interventions, out of competition, in different exhibition areas in emblematic buildings around the city.

\section{MATERIALS, OBJECTIVES AND METHODS}

In the case of Ertibil, the sources of information are the Orders and Formal Resolutions that the DFB-BFA publishes on its website ${ }^{2}$. Bilbao City Council announces the regulatory bases, which are also accessible on its website ${ }^{3}$, for the operation of Arteshop. Besides, the Faculty of Fine Arts, through the Dean for University Extension, provides the data both the number of applications and the participants finally selected in Arteshop.

As far as Arteshop is concerned, although the first edition dates from 2011, it is not until the next call when its organizers prepare and publish an official document that includes the rules of participation in this contest. For this reason, the study covers the period between 2012 and 2016 inclusive. Although during the preparation of this study, in 2017, both programs are already in operation, there are still no conclusive data and, therefore, we do not incorporate this year's data.

On the other hand, one primary objective is to analyse the distribution of the budgets that Arteshop and Ertibil dedicate to compensate the work of the participants in their calls. We also examine the results of the competitive offer of artists regarding their attendance, participation, and recurrence. This is, how many people request their involvement? How many are selected? And, what are the repetitive sequences of the applicants?

We contrast the results obtained with two theories, Thorsby's artists' work preference model (1994) and Frank and Cook's winner-take-all market theory (1995). The most important features of these arguments are summarized by Rengers (2002).

The first of these theories relies on the fact that artists must confront the challenge of maximizing the time spent in the longed-for art jobs while fulfilling the 
requirement of achieving basic budget income in unwanted non-artistic ones (Rengers 2002, 2). Concerning the second, it tries to explain the biased distributions of rewards in the art market (and other markets) and the mechanisms that lead to this distribution (idem).

\section{STARTING HYPOTHESIS}

We propose the hypothesis that the traits that define the art system as a whole are already present during the stages of formation and promotion of emerging artists. Another initial hypothesis arises from the consideration of the astonishing change that occurs in the Basque Country, and particularly in the city of Bilbao, for the political ambition and efforts made to achieve a leading position as a creative city at the international level during the three the last decades.

This second hypothesis consists in the consideration that the strategic investments made in the culture sector, and fundamentally in the promotion of art, make clear the existence of two different ways of understanding the artistic practice, which the diverse programs of Ertibil Bizkaia and Arteshop Bilbao reflect. For this reason, once we elaborate the quantitative analysis of each of the case studies, we also present a comparative analysis between both contests.

\section{ERTIBIL BIZKAIA. ITINERANT EXHIBITION OF PLASTIC ARTS}

Ertibil Bizkaia is an itinerant exhibition of visual arts, called, organized and financed by the DFB-BFA. Although it probably undergoes different changes in its configuration during its more than thirty years of existence, Ertibil regulations remain stable during the period studied. Ertibil consists of annual calls that carry out a selection of a maximum of twenty artistic works, among the applications received, which different Municipal Exhibition Halls in Bizkaia exhibit in their premises, during specific periods. 
Regulatory bases govern the yearly calls, which DFB-BFA publishes through Decrees, and their respective Formal Resolutions. It is possible to find detailed information about them on the DFB-BFA website, between 2010 and 2016 included. In these decrees and resolutions, it is possible to obtain the necessary data to carry out an empirical study of the development of the conditions of the calls.

\section{RESULTS OF THE QUANTITATIVE ANALYSIS OF ERTIBIL BIZKAIA}

Below, we present in a series of tables and figures a summary of the quantitative data extracted from the Regional Order that features the regulatory bases of Ertibil for the year 2016, which exactly coincide with those of the previous years.

In the first of these tables, we collect the quantitative data concerning the attendance $(C=$ number of applicants), participation $(P=$ number of participants) and distribution of the economic endowments included in the budget items destined to the payment of the different prizes $(Q=$ number of winners and $€=$ economic endowment of each prize), during the period studied. In the last row, we include the data regarding the total budget for the awarding of prizes in the period studied.

\begin{tabular}{|c|c|c|c|c|c|c|c|c|c|c|}
\hline \multirow[b]{2}{*}{ C } & \multirow[b]{2}{*}{$P$} & \multicolumn{2}{|c|}{$1^{\text {st }}$ prize } & \multicolumn{2}{|c|}{$2^{\text {nd }}$ prize } & \multicolumn{2}{|c|}{$3^{\text {rd }}$ prize } & \multicolumn{2}{|c|}{ Finalists } & \multirow[b]{2}{*}{ T.B. } \\
\hline & & $Q$ & $€$ & $\mathrm{Q}$ & $€$ & Q & $€$ & $Q$ & $€$ & \\
\hline 535 & 97 & 5 & 5000 & 5 & 4000 & 5 & 3000 & 82 & 2000 & 224000 \\
\hline
\end{tabular}

Table 1. Concurrence, participation, no. of prizewinners and total budget Ertibil

Reference: Own elaboration from the information obtained from the DFB/BFA decrees

Figure 1 on the next page shows the percentage relationship between excluded participants and participants. 


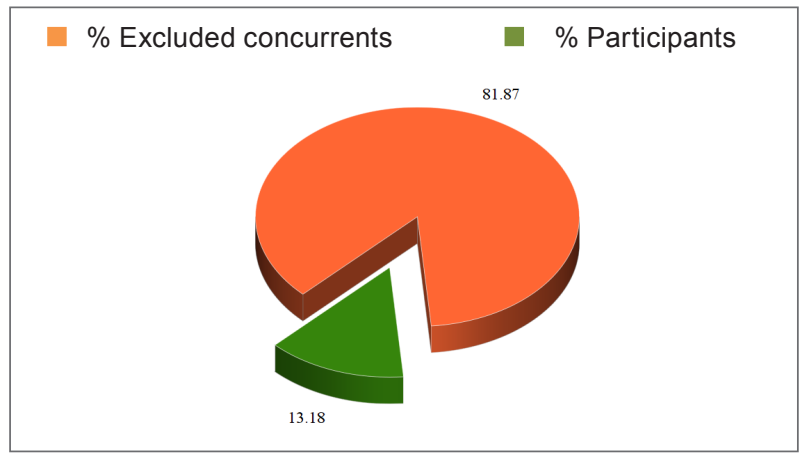

Figure 1. Comparative excluded concurrents and participants Ertibil Reference: Own elaboration from the information obtained from the DFB/BFA decrees.

Figure 2 on the left presents the economic distribution of prizes. Given these graphs, it is possible to appreciate a significant imbalance between the number of applicants and the finally selected ones, which provokes a sharp contrast in the distribution of the budget of the Ertibil contest among the applicants.

Next, in table 2, we present the recurrence, that is to say, the frequency the same person requests to participate in Ertibil. The row to the right indicates the percentage ratio of rates to the total number of applications, while the last row shows that the 534 requests to Ertibil in the period studied correspond to 294 people.

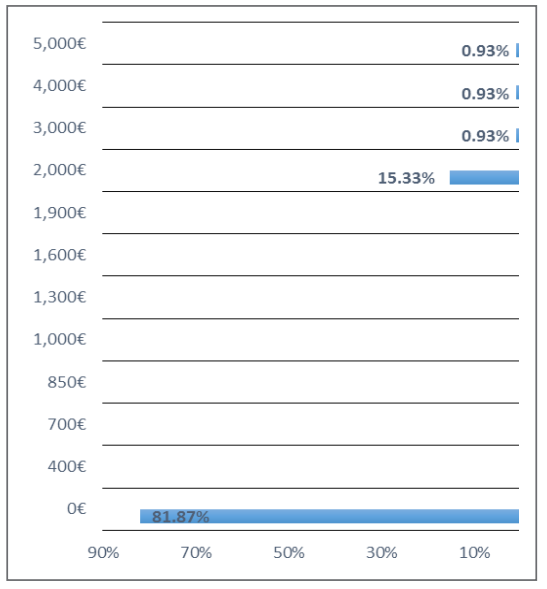

Figure 2: Distribution of the budget among the concurrents to Ertibil

Reference: Own elaboration from the information obtained from the DFB/BFA decrees.

\begin{tabular}{lcl} 
No. of concurrences & Persons & Percentage \\
\hline 1 & 164 & $55,78 \%$ \\
2 & 66 & $22,45 \%$ \\
3 & 28 & $9,52 \%$ \\
4 & 24 & $8,16 \%$ \\
5 & 12 & $4,08 \%$ \\
\hline & 294 & $100 \%$
\end{tabular}

Tabla 2. Recurrence Ertibil

Reference: Own elaboration from the information obtained from the DFB/BFA decrees. 


\section{ARTESHOP BILBAO: ONE SHOP, ONE ARTWORK}

Arteshop finds its origin as an initiative of the $\mathrm{CiB}$ (Bilbao Innovator Commerces) in 2011. According to the information that appears on its website ${ }^{4} \mathrm{CiB}$ is a meeting place between traders, consumers, service companies, associations and professionals, which aims to create a favourable climate for the introduction of innovations in shops in Bilbao. The ultimate objective of the $\mathrm{CiB}$, whose creation dates back to 2010 , is to bring innovation closer to the commercial establishments so that it can be applied to the commerce of the city of Bilbao.

To achieve this innovation, the community seeks to share ideas and information, select suppliers, participate in collaborative projects among businesses, and take advantage of the synergies that occur between commerce and sectors such as hospitality, leisure, tourism, technology and art, activities that are collected as online contents.

The CiB community operates under the auspices of Bilbao Ekintza ${ }^{5}$, a municipal entity that promotes the generation of economic and social wealth for Bilbao enhancing the city as an attractive destination for investment, creating and growing companies, improving opportunities for access to employment. The primary objectives of this entity are to lead the economic momentum and the international positioning of the city:

- Facilitating the growth of companies in their environment, supporting growth and access to new markets.

- Promoting the development of local economic activity that guarantees the quality of life of the city.

- Constituting itself as a reference in attracting events, which position it as an international reference for tourism and economic activity.

Bilbao Ekintza funding institutions, of a public nature, are the Bilbao City Council, the Provincial Council of Bizkaia, the Basque Government, the Behargintza Municipal Employment Support Centre, the Basque Employment Service Lanbide, the Bizkaia Tourist Office and the European Social Fund. The latter co-finances the entity's activities to $50 \%$.

Thus, Arteshop Bilbao takes advantage of the synergy between the artistic and the commercial activities, promoting the creative capacity of the shops, generating an unusual space for artistic expression and enriching the shopping 
experience of consumers. To this end, students of the Faculty of Fine Arts of the UPV/EHU exhibit their own artworks made exclusively for the commercial establishments of the municipality that participate in the project.

A group of artists from Bilbao Arte Foundation tutor the students of Fine Arts, as art curators, providing the students with some support in the execution of the interventions and supervising the smooth progress of their activity. Also, these artists-tutors produce artistic interventions in different emblematic buildings in the city, such as La Ribera market or the tourist office.

Unlike Ertibil, the novelty of Arteshop Bilbao implies that to achieve its consolidation, is subject to significant changes during the period studied. However, in the 2016 and 2017 editions, the regulatory bases of Arteshop Bilbao consolidate and do not undergo any changes.

\section{RESULTS OF THE QUALITATIVE ANALYSIS OF ARTESHOP BILBAO}

Next, in Table 3, we collect the data concerning the attendance ( $\mathrm{C}=$ number of applicants), participation ( $P=$ number of participants) and distribution of the budget destined to the payment of the different prizes $(Q=$ number of winners and $€=$ economic endowment of each prize) in Arteshop, during the period studied. We also include the budget for the realization of the projects for all the participants (PRP) and a partial budget destined only to the contestants of Arteshop (PPC), since this table does not include the amounts intended to the works of the artists-coordinators, which we present later.

\begin{tabular}{llllllllllllllll} 
& & \multicolumn{1}{c}{$1^{\text {st }}$ Prize } & \multicolumn{2}{c}{$2^{\text {nd }}$ Prize } & \multicolumn{1}{c}{ 3 $^{\text {er }}$ Prize } & Audience Prize & \multicolumn{3}{c}{ P.R.P. } \\
\hline Year & $\mathrm{C}$ & $\mathrm{P}$ & $\mathrm{Q}$ & $€$ & $\mathrm{Q}$ & $€$ & $\mathrm{Q}$ & $€$ & $\mathrm{Q}$ & $€$ & $\mathrm{Q}$ & $€$ & P.P.C \\
\hline 2012 & 112 & 45 & 1 & 1200 & 1 & 900 & 1 & 600 & 0 & 0 & 45 & 500 & 25200 \\
2013 & 111 & 75 & 1 & 1200 & 1 & 900 & 1 & 600 & 0 & 0 & 75 & 400 & 32700 \\
2014 & 142 & 75 & 1 & 1200 & 1 & 900 & 1 & 600 & 0 & 0 & 75 & 400 & 32700 \\
2015 & 110 & 75 & 1 & 1200 & 1 & 900 & 1 & 600 & 1 & 450 & 75 & 400 & 33150 \\
2016 & 93 & 75 & 1 & 1200 & 1 & 900 & 1 & 600 & 1 & 450 & 75 & 400 & 33150 \\
\hline Totals & 568 & 345 & & & & & & & & & & & 156.900
\end{tabular}

Table 3.Concurrence, participation, $n^{\circ}$ prizewinners and partial budget Arteshop.

Reference: Own elaboration based on the Regulatory Basis of Arteshop Bilbao. The Faculty of Fine Arts of the UPV / EHU provides data on the number of applicants and participants. 


\begin{tabular}{lllllll}
\hline Year & $\mathrm{Q}$ & $€ P$ & $€ \mathrm{C}$ & P.P.A/C & P.P.C & P.T.AB \\
\hline 2012 & 8 & 1200 & 0 & 9600 & 25200 & 34800 \\
2013 & 10 & 600 & 1000 & 16000 & 32700 & 48700 \\
2014 & 10 & 600 & 1000 & 16000 & 32700 & 48700 \\
2015 & 10 & 600 & 1000 & 16000 & 33150 & 49150 \\
2016 & 10 & 600 & 1000 & 16000 & 33150 & 49150 \\
\hline Totals & 48 & & & 73600 & 156.900 & 230.500
\end{tabular}

Table 4. Budget for artists/collaborators and total budget Arteshop

Reference: Own elaboration based on the Regulatory Basis of Arteshop Bilbao. The Faculty of Fine Arts of the UPV / EHU provides data on the number of applicants and participants.

Table 4 above shows the number of artists-coordinators A / C, the budget for the production of the works of the artists-coordinators, out of competition $(€ P)$, for their work as coordinators $(€ C)$, the partial budget of these two concepts (PPA / C), the partial budget of the contestants (PPC) and, finally, the total budget of Arteshop (PTAB) during the period studied.

Figure 3 below shows the relationship between competitors and participants in the contest, while figure 4 shows the economic distribution of the prizes.

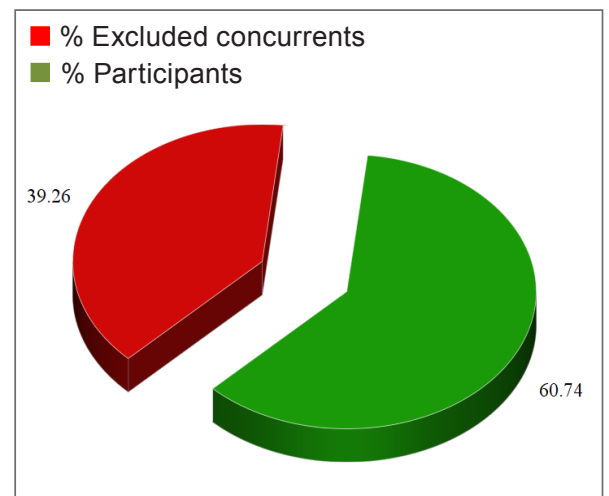

Figure 3: Comparative excluded concurrents y participants Arteshop

Reference: Own elaboration based on the Regulatory Basis of Arteshop Bilbao. The Faculty of Fine Arts of the UPV / EHU provides the data on the number of applicants and participants.

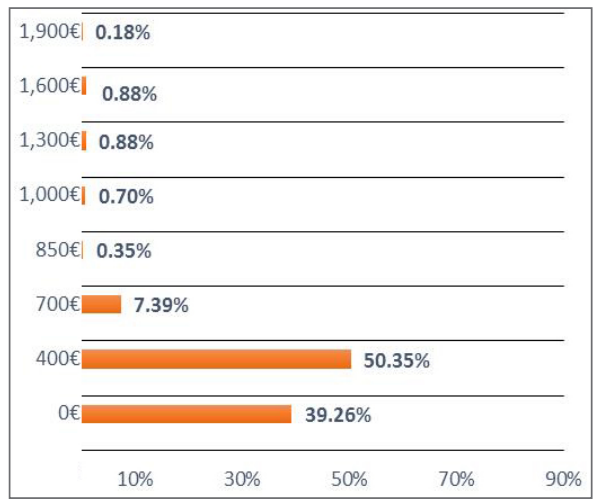

Figure 4.Distribution of the budget among the concurrentes to Arteshop.

Reference: Own elaboration based on the Regulatory Basis of Arteshop Bilbao. The Faculty of Fine Arts of the UPV / EHU provides the data on the number of applicants and participants.

Given these graphs, it is possible to appreciate a moderate imbalance between the number of applicants and the ones who are finally selected, which causes a weak contrast in the distribution of the budget of the Arteshop contest. 
Next, in table 5 we present the recurrence, that is to say, the number of people that repeatedly apply to Arteshop. The row to the right indicates the percentage ratio of frequencies to the total number of applications, while the last row indicates that the 568 applications to Arteshop in the period studied correspond to 501 people.

\begin{tabular}{lcl}
\hline $\mathrm{N}^{\circ}$ concurrences & Persons & Percentages \\
\hline 1 & 388 & $77,44 \%$ \\
2 & 84 & $16,77 \%$ \\
3 & 22 & $4,39 \%$ \\
4 & 7 & $1,40 \%$ \\
5 & 0 & 0 \\
\hline & 501 & $100 \%$ \\
\hline
\end{tabular}

Table 5. Recurrence Arteshop

Reference: Own elaboration based on the Regulatory Basis of Arteshop Bilbao. The Faculty of Fine Arts of the UPV / EHU provides data on the number of applicants and participants.

\section{COMPARATIVE ANALYSIS OF ERTIBIL AND ARTESHOP}

Before starting this section, we are in need of expressing that, confronted with the decision to compare the programs Ertibil and Arteshop, a previous discussion arises. We question the comparability of these two calls since, despite their similarities, they maintain very different features.

Firstly, concerning their respective objectives, as for the people who participate in them. Besides, we propose the difference between training and professionalization, directed both at the traditional art system and at the expanded field of cultural industries.

Perhaps from the field of economics, there would not be such objections to compare, in quantitative terms, these two contests. However, in their qualitative analysis, specific nuances would surely escape, which only within the field of art there is any possibility of discernment. After some debate on this problem, we conclude it is necessary when comparing these calls qualitatively, to define whether the groups of persons that request to participate in both contests are equivalent or comparable in some way. 
To do this, it is necessary, firstly, to discriminate applicants by age, since Ertibil establishes an access barrier that prevents artists over 35 years to applicate, while in Arteshop there is no age limit. On the other hand, while in Arteshop only students from the Faculty of Fine Arts at the UPV/EHU can attend, in Ertibil, in addition to this collective, another category is also included; people registered as citizens in Biscay. This license should not cause strangeness, since, as Zorloni points out, there are no formal entry barriers in the supply chain of the art market, since anyone can claim to be an artist $(2013,25)$.

When we contact the Provincial Council of Bizkaia to obtain a list of the competitors in each category, who applied to participate in Ertibil in the period studied, we are informed that they do not keep a record of who are students of the Faculty of Fine Arts of the UPV/EHU (FFA-UPV/EHU) and who are not. Their registers only allow discerning between the concurrentes registered in Biscay and the ones who are not registered in this province and are students at the FFA-UPV/EHU. We also try to obtain this information, in addition to the applicants of Arteshop over 35 years, through the UPV/EHU. The answer is that they cannot provide this data because of the existence of a law of personal data protection that prevents it.

Therefore, it is not possible to establish whether these two groups of applicants, to Ertibil and Arteshop, are equivalent. In any case, we decide to go ahead with the comparative quantitative analysis, relying exclusively on the names and surnames of the applicants, despite this bias caused by the inability to check all the data necessary to carry out this analysis more rigorously.

Ultimately, the primary objective of this study is not to compare the profile of the applicants, but the economic conditions that these calls manifest in their bases and the quantitative answer of these applicants, be they students, artists or any individual registered in Bizkaia, in the case of Ertibil. In this sense, the first fact that strikes us is that among all the applicants, 294 in Ertibil and 501 in Arteshop, only 91 of them decide to apply for both calls, $30.95 \%$ and $18.16 \%$, respectively. This data, together with the information offered in Table 6, which compares the recurrences of both calls, indicates that the groups of applicants belong to two quite different universes. 


\begin{tabular}{lll}
\cline { 2 - 3 } & Ertibil & Arteshop \\
\hline $\mathrm{N}^{\circ}$ concurrences & Persons & Percentages \\
\hline 1 & $55,78 \%$ & $77,44 \%$ \\
2 & $22,45 \%$ & $16,77 \%$ \\
3 & $9,52 \%$ & $4,39 \%$ \\
4 & $8,16 \%$ & $1,40 \%$ \\
5 & $4,08 \%$ & 0 \\
\hline
\end{tabular}

Table 6. Comparative of recurrences between Ertibil and Arteshop

Reference: own elaboration from tables 2 Y 6.

Although, as we just remind, there are more applicants in Arteshop than in Ertibil, there is a considerable amount of artists/students who decide to apply repeatedly for this last call. In any case, in both calls the number of applicants who apply only once is very high, $55.78 \%$ and $77.44 \%$ respectively.

These facts lead me to consider Rosen's statement; the professionals competing in these markets are very clear about their chances of succeeding in it, and when they are not clear, they give up easily (Rosen 1996, 135).

It is also pertinent to point out, in view of the greater number of applications in Arteshop than in Ertibil, one of the characteristics of the artistic labour market that Benhamou proposes; to succeed in the art market, more than an academic title it is crucial to get a good reputation and the more activities an artist includes in their curriculum, the greater their reputation (Benhamou 2003, 70).

In this sense, the greater convening power Arteshop shows, can be due to the fact that the applicants are more likely to be accepted in this call, rather than in Ertibil -and, therefore, it is easier to obtain the corresponding certificate of participation in Arteshop, in order to increase their curriculum and thus their reputation-as it can be seen in figure 5 following which compiles figures 4 and 6 above.

It should also be taken into account that Arteshop, in addition to having a greater ability to summon because the access barrier is less restrictive than that of Ertibil, it gives every selected applicant a certain economic amount for their labour and for the production of their artworks, which in Ertibil does not occur. 


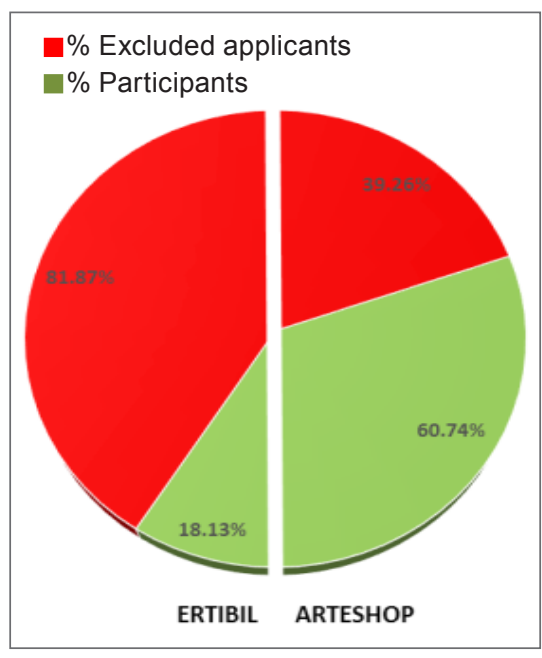

Figure 5: Comparison between the percentages of excluded applicants and participants of Arteshop and Ertibil.

Reference: own elaboration from tables 2 Y 6.
Applicants to Ertibil meet the requirement of having to pay for themselves the costs of producing the works presented or requesting scholarships or external aid for their production. It is for these reasons that we find it paradoxical that, despite this double 'call effect' of Arteshop, the repeated concurrence to Ertibil presents more significant proportions.

We understand that a good reason for it is the increasing prestige Ertibil achieves along time that makes the rewards in this call are symbolically greater. Being a more competitive call may be the reason that applicants who really want to be among the few chosen ones decide to try more times than the applicants to Arteshop.

On the other hand, Ertibil is more linked to the Art System -with capital lettersthan Arteshop and, although being selected in Ertibil is not a guarantee to succeed in the art system, it has more value regarding the reputation winners obtain in this contest. Another reason may be that the economic value of the prizes in Ertibil is considerably higher than in Arteshop.

In this sense, we find striking the similarity between the economic resources that both calls set for the payment of the prizes and, in the case of Arteshop, the production costs and materials of the works made by both the students and the artists- tutors, as well as for tutoring the latter; $€ 230,500$ in Arteshop and $€ 224,000$ in Ertibil.

The distribution of these amounts is significantly different between calls, as can be seen in figure 6 following which compiles Figures 2 and 4 above. Both Ertibil and Arteshop present an unbalanced distribution of economic resources among the applicants, confirming Frank and Cook's theory of winner-take-all markets. In any case, this feature is more pronounced in Ertibil than in Arteshop. While in Ertibil $81.87 \%$ of the people attending are outside the economic division, this amount is reduced to $39.26 \%$ in Arteshop, although, at the same time, $50.35 \%$ perceive an almost testimonial amount for their work. 


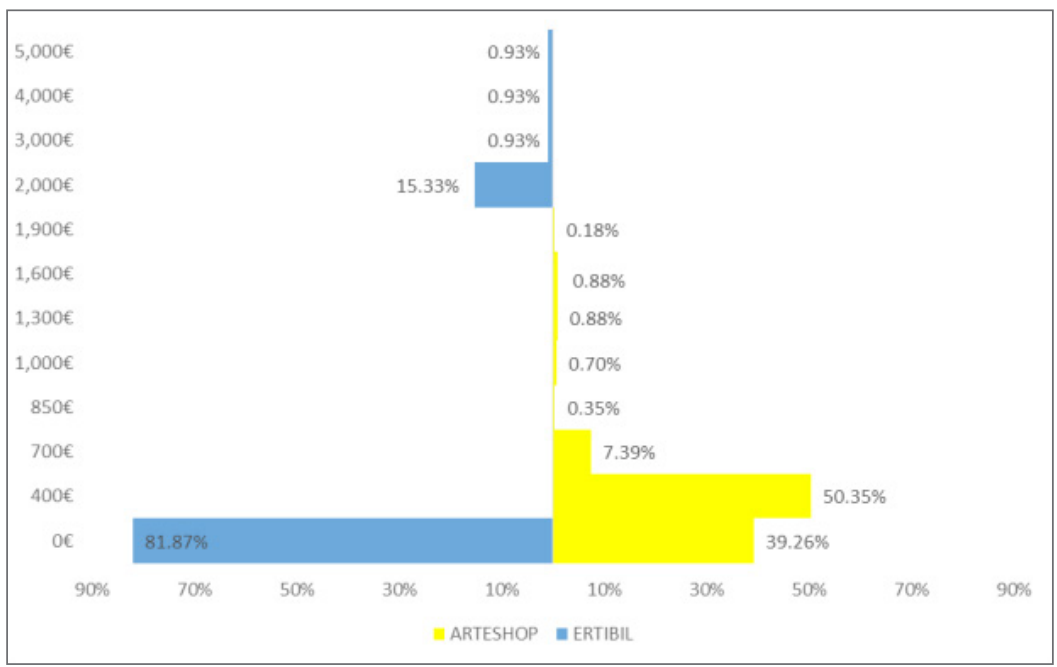

Figure 6. Comparative of the budget distributions of Ertibil and Arteshop

Reference: own elaboration from figures 2 and 4.

It is also worth mentioning the introduction of the figure of the artist-tutor in Arteshop programme, who perceives a certain amount for the production of artworks, intended for exhibition outside of competition in emblematic commercial spaces of the city, in addition to receiving a remuneration for the coordination of the work of the selected proposals in the participating establishments.

The remuneration as a tutor is much higher than the one they receive for their artistic work, and it makes visible the fact that the artists receive a lower economic compensation for this later work. In addition, artists must face the obligation of having to perform works not related to artistic practice -although related to art- in order to carry out their artistic work.

\section{SOME CONCLUSIONS AND RECOMMENDATIONS}

The comparative analysis of Ertibil and Arteshop confirms that the main characteristics of the reference functions, both of Thorsby and of Frank and Cook, are in these processes of promotion of artists in the initial stages of their studied careers. 
On the one hand, Ertibil Bizkaia distributes very unequally the budget to compensate competitors, which has a system that privileges a few participants, while maintaining a percentage of outsiders. The system is only sustainable if it gives access to a very limited number of professionals.

This disproportion is less pronounced in Arteshop, which can have two readings; On the one hand, it may be that the organizers are aware of this fact and manage to establish a more equitable and inclusive distribution system of the available budget. In this way, the real situation of the artistic labour market, in general, becomes evident, it is a market in which economic rewards are meagre and produce large pockets of precariousness.

In addition, if we compare the budgets of Ertibil and Arteshop with the 390,000 $€$ of base budget for the competitive competition (Guggenheim Bilbao Museum, 2017), destined to contract the maintenance service of Puppy, an emblematic work of the 'Guggenheim effect', we can conclude that the traits of the 'winner-take-all markets' theory are exponentially progressive constants in the art system.

However, even the large numbers that manage the system and the art business as a whole are not significant when compared in macroeconomic terms. As Juan Antonio Ramírez points out $(2010,38)$, the contribution of art to the economic progress of society is not really as important as some agents of the sector claim, provided that we consider things with conventional accounting methods.

On the other hand, these comparisons are not very relevant, since the task of establishing a correlation, between the micro-level analysis that this section occupies and that of the art system as a whole, depends on very heterogeneous and partial information sources that offer very different results (Ramírez 2010,38 ). Besides, economics today seems to us a pseudoscience, not much less rigorous than art criticism, although it is covered by the prestige that its fondness for deceptive mathematical models, inevitably quantitative, gives it (39).

Therefore, an issue to consider is how artists respond to this problem through the works presented in these contests. These answers can be obtained either through these works or through the statements their authors make about them. In the case of Ertibil, it is possible to carry out such an analysis since annually the DFB/BFA edit and publish a catalogue, which informs about the selected 
artists and works and, in addition, gives reasons for the choice of artworks selected.

On the contrary, Arteshop does not carry out a historical record of the participating works, which causes great difficulty when making the effort to analyze, which of the works presented in this contest offer a criticism or comment, to this economic situation experienced by its authors. As Boris Groys argues, "there is an important difference between art and commercial mass culture: art has a file at its disposal, and mass culture does not" (Groys 2002, 59).

And, of course, in order to carry out the analysis we propose:

A historical archive is needed, through which several periods can be compared in time, including the present. [...] And given that the individual person is obviously incapable of such a broad general historical vision, they direct us to the archives of our culture to carry out a historical diagnosis of that kind. If in doing so we turn to the art sector, then we must make sure that it is the archive of the valued artistic tradition, as represented in the museum's collections, books on the history of art and practical artistic instruction, that not only makes possible diagnosis but also requires that it be done.

(Groys 2002, 59)

\section{References}

Benhamou, Françoise. 2003. "Artists' labour markets". In A handbook of cultural economics, edited by Ruth Towse, 69-75. Cheltenham, UK: Edward Elgar

Frank, Robert H. \&Philip J. Cook. 1995. The winner-take-all society. New York: Penguin

Florida, Richard L. 2002. The rise of the creative class, and How it is transforming work, leisure, community and everyday life. New York: Basic Books

Groys, Boris. 2002. "The artist as consumer". In Shopping: a century of art and consumer culture, edited by Christoph Grunenberg and Max Hollein. Ostfildern-Ruit: Hatje Cantz

Horkheimer, Max \& Theodor W. Adorno. [1944] 1947. Dialektik der Aufklärung. Amsterdam: Querido

Landry, Charles \& Franco Bianchini. 1995. The creative city.London:Demos

Landry, Charles. 2005. "Lineages of the creative city". In Creativity and the City, Creativity and the city: How the creative economy changes the city, edited by Simon Franke and Evert Verhagen. Rotterdam: Netherlands Architecture Institute 
Plaza Inchausti, María Beatriz. 1999. "The Guggenheim-Bilbao museum effect”. International Journal of Urban and Regional Research 233: 589-92

Plaza Inchausti, María Beatriz, Manuel Tironi \& Silke N. Haarich. 2009. "Bilbao's art scene and the 'Guggenheim effect' revisited”. European Planning Studies 17: 1711-29

Ramírez Domínguez, Juan Antonio. 2010. “El arte no es el capital: Arte y economía”. In El sistema del arte en España, J.A. Ramírez, ed. Madrid: Cátedra

Rengers, Merijn. 2002. "Economic lives of artists: Studies into careers and the labour market in the cultural sector". Doctoral dissertation, Utrecht University

Romo Guijarro, José Angel. 1999. "El Museo Guggenheim, Bilbao y la identidad de los vascos". Thémata 23: 215-21

Rosen, Sherwin. 1996. Book review: The winner-take-all society by Robert H. Frank\& Philip J. Cook. Journal of Economic Literature 34: 133-6

Throsby, David. 1994. "A work-preference model of artist behavior". In Cultural economics and cultural policies, edited by Alan Peacock \& Ilde Rizzo, 69-80. Dordrecht: Kluwer

Yencken, David. 1988. “The creative city”. Meanjin 47(4): 597-608

Zorloni, Alessia. 2013. The economics of contemporary art: Markets, strategies and stardom. Berlin: Springer

Notes

* This work is included in the research labours of Prekariart team at the University of the Basque Country UPV/EHU financially supported by the Spanish Ministry of Economy and Competitiveness (MINECO) - more specifically from the State $I+D+i$ Programme Oriented to the Challenges of Society, ref. HAR2016-77767-R (AEI/FEDER, UE) - that the authors gratefully acknowledge.

${ }^{1}$ http://creativecitiesindex.org/index.php?l=2

${ }^{2}$ Diputación Foral de Bizkaia / Bizkaiko Foru Aldundia DFB/BFA: Decrees and Formal Resolutions Ertibil Bizkaia 2012-2016: https://goo.gl/EGuu43.

${ }^{3}$ Bases reguladorasArteshop Bilbao 2012 - https://goo.gl/AC7gqU; Arteshop 2013 - https://goo. gl/xbdWzW; Arteshop 2014 - https://goo.gl/Zrgvff; Arteshop 2015-https://goo.gl/XcR2Ja \& Arteshop 2016 - https://goo.gl/ZyBAzL.

${ }^{4} \mathrm{http}: / / c i b i l b a o . c o m / q u e-e s-e l-c i b /$.

${ }^{5}$ http://www.bilbao.eus/lanekintza/.

(Artículo recibido 20-11-2017; aceptado 12-12-2017) 